\author{
Near East University Journal of Education Faculty (NEUJEF) \\ Received: March 05, 2019 Revised: April 17, 2019 Accepted: June 05, 2019
}

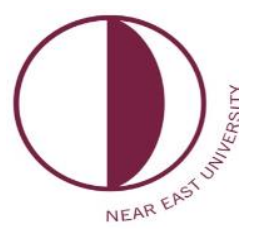

\title{
EVALUATION OF THE STUDIES ON TECHNOLOGY LEADERSHIP: A CONTENT ANALYSIS
}

\author{
Yucehan Yucesoy ${ }^{1 *}$, Gokmen Dagli ${ }^{2}$ \\ ${ }^{1}$ Department of Classroom Teaching, Atatürk Faculty of Education, Near East University, North Cyprus, \\ Mersin 10 Turkey, yucehan.yucesoy@neu.edu.tr \\ ${ }^{2}$ Faculty of Education, University of Kyrenia, Kyrenia, North Cyprus, Mersin 10 Turkey, \\ gokmen.dagli@kyrenia.edu.tr \\ Correspondence: yucehan.yucesoy@neu.edu.tr ; Tel.: +0392 2236464
}

\begin{abstract}
A technology leader is the person who establishes the relationship between technology and leadership by trying to reconcile human and information technology components as the most important in this process by taking an active role in executing the technology. This study aims to determine the current trends in the published articles on technology leadership in order to provide a review on these studies. Data of the study were obtained from ERIC database by searching "technology leadership" and a total number of 53 articles were obtained. The obtained data were examined based on content analysis criteria including year of publication, country, research method, subject, sample, data collection tool and data analysis method. Data were analyzed and provided with frequency and percentages and shown with tables and figures. Results are discussed with relevant literature and recommendations for further research and practices are provided.
\end{abstract}

Keywords: technology leadership, technology, content analysis

\section{Introduction}

Technological innovations and developments affect the education system and teachinglearning-process in this context. The technologies used in education are leaving their place to new technologies. Increasingly, they take their place in the classroom environment such as computer, projection, electronic board, distance education and the learning environment is moved to the network environment (Bulman \& Fairlie, 2016; Sendurur \& Arslan, 2017).

As the information age, it ensures the continuous development of technology and therefore technology is indispensable in every stage of our lives. It is unthinkable that education does not keep up with these developments in our age when everything changes so fast. Today, technology is being tried to be integrated into all processes of education. Researchers emphasizing that technology integration is important, stated that although there is no definite definition of technology integration in schools, teachers can use it as any technology to increase student achievement in classrooms (Hew \& Brush, 2007).

Technology is seen by many educators, teachers and researchers as indicators of high quality in education. In order to educate individuals who access and use information, teachers and school managers who have an important role in educational practices to be effective should be 
able to use technological tools effectively and have these skills. According to Creighton (2003), a technology leader is defined as a person who possesses technology skills, leads and follows new technological developments, affects teachers, students and other people in this subject, enables them to use technology and integrates technology with other fields. Technology leadership is described as the main role of school administrators in using current technological innovations effectively in education. General characteristics of a technology leader is predicted as having visionary leadership, digital age learning culture, excellence in professional practice and systematic development. Expectations from technology leaders are teaching senior computer skills, preparing and updating web page of school, carrying out advertising studies, developing digital course material, designing interactive education videos and teaching inservice practices to school principals in terms of technology (Sugar \& Holloman, 2009; Dexter, 2018).

Today, technology is being tried to be integrated into all processes of education, but this integration process inevitably faces some barriers. Technology leadership is at the center of these barriers since the success of all change and development activities in an educational institution depends on the management understanding in that institution. Therefore, changes and new responsibilities have emerged in the roles and responsibilities of school principals, who play a critical role in the integration of technology into education, for the efficient use of technology in teaching and learning (Flanagan \& Jacobsen, 2003; Anderson \& Dexter, 2005; Akbaba, Altun \& Gurer, 2008; Akcil, Altinay, Dagli \& Altinay, 2019). These new roles and responsibilities led experts to look for standard answers to questions such as who the technology leader is, what competences he has, and what his roles are.

As in all fields of education, it is important to redefine the competencies of school principals over time, to ensure their development and to identify the barriers to their development. With the dominance of technology, the need for school principals to adapt themselves to technological developments and to improve themselves in this field is gaining importance every passing day. The changing and increasing diversity of education has increased competition between schools and the need for schools to create effective learning environments; therefore, it has also imposed new roles and responsibilities on school principals. With the development of technology in all areas of education, school principals are expected to assume a leadership role in using and implementing technology (Hacifazlioglu, Karadeniz \& Dalgic, 2010). It has become a necessity for school principals to acquire responsibilities and to acquire and develop certain competencies in order to fulfill their responsibilities as technological leaders.

It is important to re-determine the competencies of school principals over time, to ensure their development and to identify the barriers to their development. With the dominance of technology in the new age, the need for school principals to adapt themselves to technological developments and to develop themselves in this field gains importance every day. Some of the qualifications that school principals should have about educational technologies are understanding the basic concepts of computer and technology, recognition of basic software and hardware, knowing the features to be considered in the selection and evaluation of software and hardware, develop vision for using technology in school, search and find resources for technology acquisition and identifying the areas of use of technology. The expected technology leadership role of school administrators includes all organizational decisions, policies and activities that facilitate the effective use of educational technology in the school. Some positive results of a successful technology leadership for the school can be listed as follows:

- Students' academic achievement improves. 
- Students' attendance increases.

- Students' burnout decreases.

- A better education environment is prepared for the students.

- Provides more effective management activities.

- Reduces burnout of teachers and other employees (Afshari, Bakar, Luan, Samah \& Fooi, 2009; Weng \& Tang, 2014).

Considering the importance of an effective technology leadership, this study aims to determine the current trends in the published articles on technology leadership in order to provide a review on these studies. In line with this general aim, answers to the following questions were sought in the study:

1. What is the distribution of the articles on technology leadership based on year of publication?

2. What is the distribution of the articles on technology leadership based on publication of country?

3. What is the distribution of the articles on technology leadership based on research method?

4. What is the distribution of the articles on technology leadership based on subject?

5. What is the distribution of the articles on technology leadership based on sample?

6. What is the distribution of the articles on technology leadership based on data collection tool?

7. What is the distribution of the articles on technology leadership based on data analysis method?

\section{Method}

\subsection{Research Model}

Descriptive survey model was used in this research. Descriptive research tries to describe and explain the events, objects, assets, institutions, groups and various variables related to a certain subject or discipline. In this way, it provides the ability to understand and group them well and the relations between them are determined (Karasar, 2009). In the descriptive survey model, observation, recording, detecting the relations between events and generalizing on the invariant principles controlled are included. In other words, the description function of science is in the foreground (Yildirim \& Simsek, 2006). In this study, the articles related to technology leadership obtained from ERIC (Education Resources Information Center) database have been analyzed and explained in terms of various variables.

\subsection{Content Analysis Criteria}

In order to examine the studies on technology leadership in the last five years, all articles published in the ERIC database since 2015 have been systematically searched. The selected articles were analyzed according to the previously determined content analysis criteria 
including year of publication, country, research method, subject, sample, data collection tool and data analysis method used in the studies on technology leadership.

\subsection{Data Collection}

Data of the study involved the published documents on technology leadership in ERIC database. The published documents were searched and identified by the researchers and a total number of 53 published documents were obtained for the study. Figure 1 shows the search page of studies on technology leadership in ERIC.

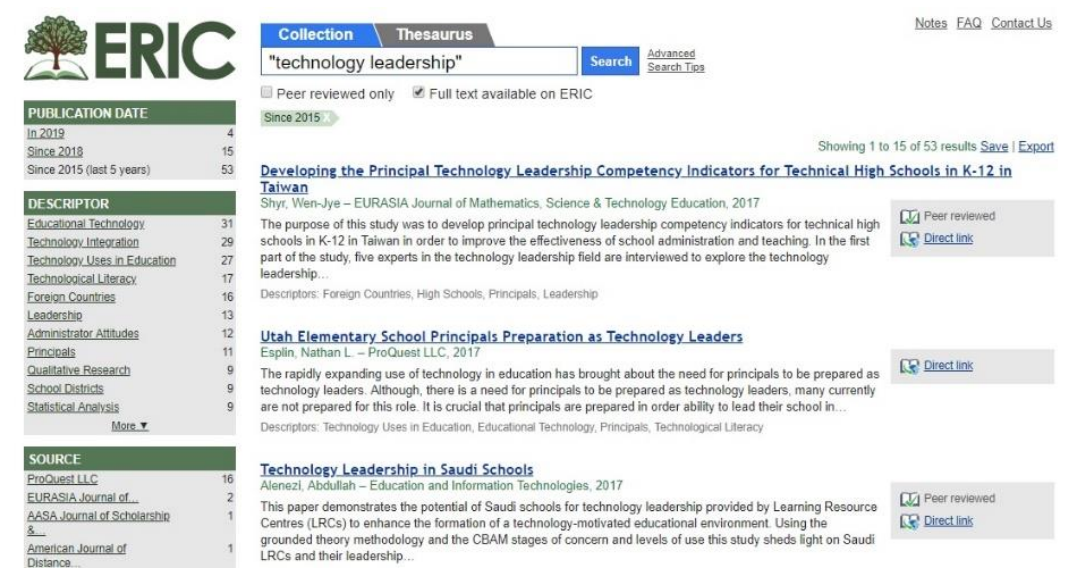

Figure 1. Technology leadership search page in ERIC

\subsection{Data Analysis}

For data analysis, all obtained data were entered into SPSS 23.00 program and analyzed based on the previously determined content analysis criteria. Descriptive statistics, frequencies and percentages were applied and shown with tables in terms of results.

\section{Results}

\subsection{Distribution of the Articles based on the Year of Publication}

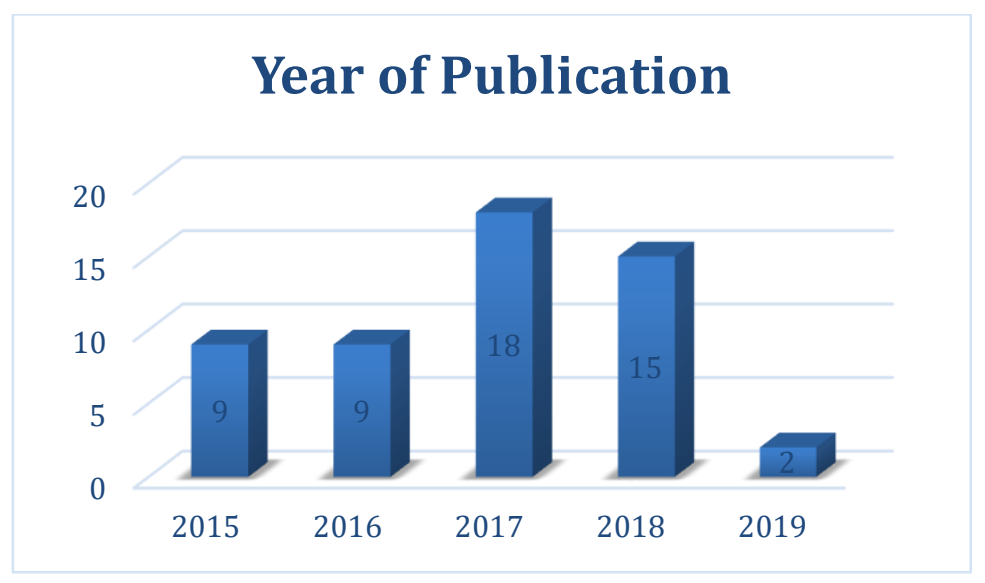

Figure 2. Distribution of the articles based on the year of publication 
Figure 2 shows the distribution of the articles on technology leadership based on the year of publication in ERIC database. The years between 2015 and 2019 are included in the figure. The articles for the year of 2019 has been included into the study until May. As it can be seen from the figure, there are 9 published documents in 2015, 9 published documents in 2016 and 18 published documents in 2017, 15 published documents in 2018 out of the 53 articles analyzed in the study. As it can be seen, there is a steady increase in the number of publications related with ABA throughout the years and only 2 articles have been published until this month. According to the results, it can be said that there is a steady increase in the number of published articles on technology leadership throughout the years.

\subsection{Distribution of the Articles based on the Country of Publication}

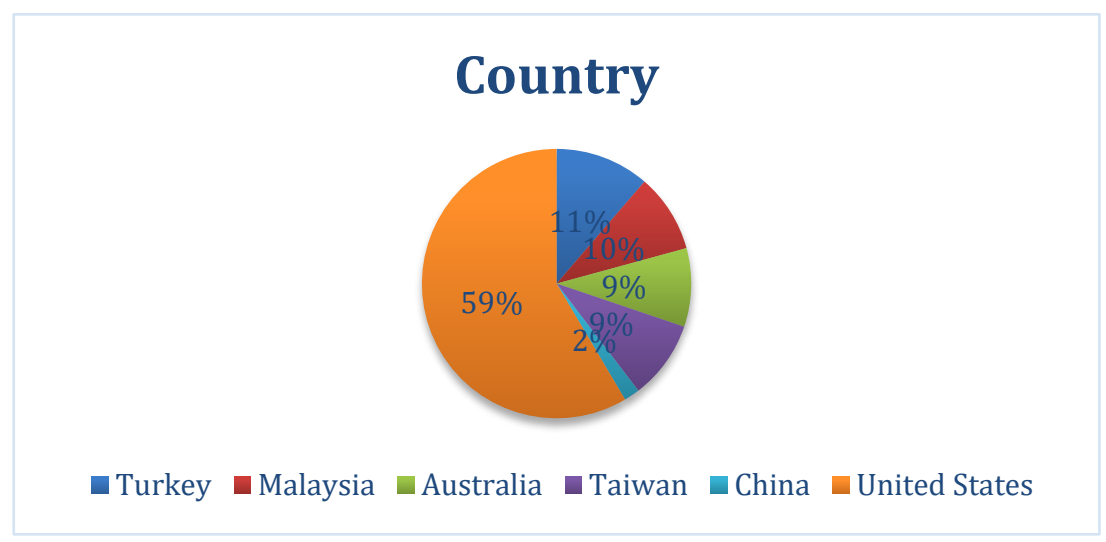

Figure 3. Distribution of the articles based on the country of publication

Figure 3 shows the distribution of the published documents based on the countries. When the results are examined, it is seen that majority of the articles were published by the authors from United States (59\%) and Turkey is the second frequent country of the authors (11\%). In addition, these results were followed by Malaysia, Australia (9\%), Taiwan (9\%) and China $(2 \%)$.

\subsection{Distribution of the Articles based on the Research Method}

Table 1. Distribution of the articles based on the research method

\begin{tabular}{lcc}
\hline Research Method & $\boldsymbol{F}$ & $\boldsymbol{\%}$ \\
\hline Quantitative & 32 & 60.4 \\
Qualitative & 14 & 26.4 \\
Mixed & 7 & 13.2 \\
Total & 53 & 100 \\
\hline
\end{tabular}


Results on the distribution of the articles based on the research method are provided in Table 1. As it can be seen, quantitative research method was the most frequently used method in the articles on technology leadership ( $\mathrm{f}=32,60.4 \%)$. This is followed by qualitative research method $(\mathrm{f}=14,26.4 \%)$ and mixed research method $(\mathrm{f}=7,13.2 \%)$. Therefore, it can be inferred that mixed research method is the least preferred method in the examined articles on technology leadership.

\subsection{Distribution of the Articles based on the Subject}

Table 2. Distribution of the articles based on the subject

\begin{tabular}{llc}
\hline Subject & $\boldsymbol{F}$ & \% \\
\hline Technology leadership competency & 21 & 39.6 \\
Determinants of technology leadership & 13 & 24.5 \\
Preparing school principals as technology & 9 & 17.0 \\
leaders & & \\
Preparing schools for technology leadership & 8 & 15.1 \\
Online technology leadership course for & 2 & 3.8 \\
master students & & 100 \\
Total & 53 &
\end{tabular}

Table 2 shows the distribution of the articles based on the subject area. According to the table, the first most frequently studied subject area was technology leadership competency $(\mathrm{f}=21,39.6 \%)$. As it can be seen, determinants of technology leadership was the second frequently studied subject area with 13 published documents. Results showed that there are 9 studies on preparing school principals as technology leaders, 8 studies on preparing schools for technology leadership and 2 studies on online technology leadership course master students.

\subsection{Distribution of the Articles based on the Sample}

Table 3. Distribution of the articles based on the sample

\begin{tabular}{lcc}
\hline Sample & $\boldsymbol{F}$ & \% \\
\hline Elementary school principals & 18 & 34.0 \\
High school principals & 17 & 32.1 \\
School librarians & 7 & 13.2 \\
Document analysis & 7 & 13.2 \\
Master students & 2 & 3.8 \\
Higher education principals & 2 & 3.8 \\
Total & 53 & 100 \\
\hline
\end{tabular}


Table 3 demonstrates the distribution of the articles based on the sample. According to the table, it is seen that elementary school principals and high school principals were the most frequently studied research sample in the studies on technology leadership in ERIC database. School librarians, master students and higher education principals were the other studies research sample groups. In addition, documents were frequently analyzed in the articles.

\subsection{Distribution of the Articles based on the Data Collection Tool}

Table 4. Distribution of the articles based on the data collection tool

\begin{tabular}{lcc}
\hline Data collection tool & $\boldsymbol{F}$ & $\boldsymbol{\%}$ \\
\hline Questionnaire & 27 & 50.9 \\
\hline Interview form and questionnaire & 14 & 26.4 \\
\hline Interview form & 9 & 17.0 \\
\hline Document & 3 & 5.7 \\
\hline Total & 53 & 100 \\
\hline
\end{tabular}

Table 4 shows the distribution of the articles based on the data collection tool. As it can be seen, questionnaires were the most frequently used data collection tools in the studies on technology leadership $(\mathrm{f}=27,50.9 \%)$. This result is followed by interview form and questionnaire used together $(\mathrm{f}=14,26.4 \%)$. Interview form and documents were less frequently used data collection tools when compared to other data collection tools.

\subsection{Distribution of the Articles based on the Data Analysis Method}

Table 5. Distribution of the articles based on the data analysis method

\begin{tabular}{llc}
\hline Data Analysis Method & $\boldsymbol{F}$ & \% \\
\hline SPSS & 24 & 45.3 \\
Induction & 15 & 28.3 \\
Qualitative analysis and SPSS & 14 & 26.4 \\
Total & 53 & 100 \\
\hline
\end{tabular}

Table 5 shows the distribution of the articles based on the data analysis method. Results showed that researchers frequently preferred to use SPSS program $(\mathrm{f}=24,45.3 \%)$. In addition, induction $(\mathrm{f}=15,28.3 \%)$ and qualitative analysis and SPSS together $(\mathrm{f}=14,26.4 \%)$. were also used as data analysis methods in the studies on technology leadership in ERIC database. 


\section{Discussion}

The current study aimed to determine the trends in the published articles on technology leadership in ERIC database in order to provide a review on these studies. Articles were searched, identified and examined based on certain inclusion criteria. These inclusion criteria were year of publication, country, subject, research method, sample, data collection tool and data analysis method. Results showed that there is a steady increase in the number of published articles on technology leadership throughout the years. This might be due to the increasing importance given to the critical role of technology leadership in the last years for effective educational environments and practices (Webster, 2017; Durnali, 2019).

According to the results, United States is the most frequent country in which the researches on technology leadership carried out. Results also showed that elementary school principals and high school principals were the most frequently studied research sample, questionnaire was mostly used data collection tool and SPSS was the most frequently data analysis method in terms of quantitative analysis.

Furthermore, quantitative research method was the most frequently used method in the articles and the first most frequently studied subject area was technology leadership competency and determinants of technology leadership. School principals perform technology leadership behaviors whether they have sufficient knowledge and skills to be able to bring about, how much technology will be used in educational activities and how much success will be effective. In this context, it is very important for school principals to have technology leadership competencies in order to use technology effectively in educational environments. According to Gurfidan and Koc (2016) stated that technology integration into education is a complicated process and there is a need to investigate the school wide factors for an effective technology leadership.

\section{Conclusion and Recommendations}

The ultimate goal of this paper was to carry out a content analysis study in order to provide an evaluation on the studies related with technology leadership published in ERIC database. It is expected that this study would shed light to further research and practices on technology leadership since it provided the trends in the studies. Based on the obtained results of the present study, the following recommendations for further research and practices are provided:

-Other international academic databases might be analyzed in order to figure out the trends in the articles on technology leadership.

-This study analyzed the articles on technology leadership, further studies might examine the postgraduate thesis in the related field in order to determine the trends.

-Other content analysis criteria including number of authors, keywords and citations might be used to point out the trends in the articles on technology leadership. 


\section{References}

Afshari, M., Bakar, K. A., Luan, W. S., Samah, B. A. \& Fooi, F. S. (2009). Technology and school leadership. Technology, Pedagogy and Education, 18(2), 235-248.

Akbaba-Altun, S., \& Gurer, M. D. (2008). School administrators' perceptions of their roles regarding information technology classrooms. Eurasian Journal of Educational Research (EJER), 33, 35-54.

Akcil, U., Altinay, Z., Dagli, G., \& Altinay, F. (2019). The role of technology leadership: Innovation for school leadership in digital age. eLearning \& Software for Education, 2, 323-329.

Anderson, R. E. \& Dexter, S. (2005). School technology leadership: An empirical investigation of prevalence and effect. Educational Administration Quarterly, 41, 49-82.

Bulman, G., \& Fairlie, R. W. (2016). Technology and education: Computers, software, and the internet. In Handbook of the Economics of Education (Vol. 5, pp. 239-280). UK: Elsevier.

Creighton, T. (2003). The principal as technology leader. Corwin: Corwin Press.

Dexter, S. (2018). The role of leadership for information technology in education: Systems of practices. Second Handbook of Information Technology in Primary and Secondary Education, 483-498.

Durnali, M. (2019). Ortaokul Öğretmenlerinin Görüşlerine Göre Okul Müdürlerinin Sergilediği Teknolojik Liderlik Davranış Düzeyi. Kuramsal Eğitimbilim Dergisi, 12(2), 401-430.

Flanagan, L. \& Jacobsen, M. (2003). Technology leadership for the twenty-first century principal. Journal of Educational Administration, 41(2), 124-142.

Gurfidan, H., \& Koc, M. (2016). The Impact of School Culture, Technology Leadership, and Support Services on Teachers' Technology Integration: A Structural Equation Modeling. Education \& Science/Egitim ve Bilim, 41(188), 99-116.

Hacifazlioglu, O., Karadeniz, S., \& Dalgic, G. (2010). Egitim yoneticileri teknoloji liderligi standartlarina iliskin ogretmen, yonetici ve denetmenlerin gorusleri. Kuram ve Uygulamada Egitim Yonetimi, 16(4), 537-577.

Hew, K. F., \& Brush, T. (2007). Integrating technology into K-12 teaching and learning: Current knowledge gaps and recommendations for future research. Educational Technology Research and Development, 55(3), 223-252.

Karasar, N. (2009). Bilimsel arastirma yontemi: Kavramlar-ilkeler-teknikler. Ankara: Nobel Yayin Dağitim.

Sendurur, P., \& Arslan, S. (2017). Egitimde teknoloji entegrasyonunu etkileyen faktorlerdeki degisim. Mehmet Akif Ersoy Universitesi Egitim Fakultesi Dergisi, 1(43), 25-50.

Sugar, W., \& Holloman, H. (2009). Technology leaders wanted: Acknowledging the leadership role of a technology coordinator. TechTrends, 53(6), 66-74.

Webster, M. D. (2017). Philosophy of technology assumptions in educational technology leadership. Journal of Educational Technology \& Society, 20(1), 25-36. 
Weng, C. H., \& Tang, Y. (2014). The relationship between technology leadership strategies and effectiveness of school administration: An empirical study. Computers \& Education, 76, 91-107.

Yildirim, A., \& Simsek, H. (2006). Sosyal bilimlerde nitel arastirma yontemleri. Ankara: Seckin Publishing.

\section{Biodata of the Corresponding Author}

Yucehan Yucesoy is lecturer in the department of Classroom Teaching at Near East University, North Cyprus. He is a PHd student at the department of Education Management, Supervision, Economy and Planning. He teaches visual arts, teaching arts skills and instructional technologies and material design. 